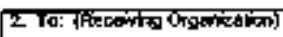

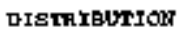

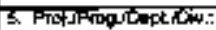

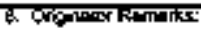

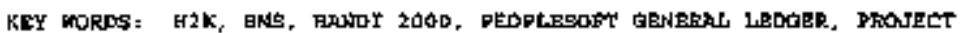

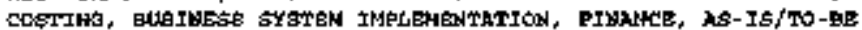
11. Rabiviter Romeris:

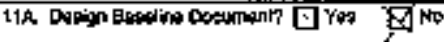

AHWDI 2000

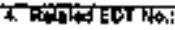 \\ $r_{1} / \mathrm{A}$

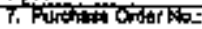 \\ $\boldsymbol{p} / \mathrm{k}$

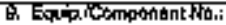 \\ 2)/}

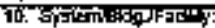

$n / A$

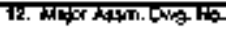

$\mathbf{N} / \mathbf{A}$

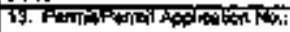

$\mathbf{N} / \mathbf{A}$

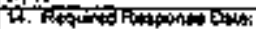

$\mathbf{H} / \mathbf{A}$

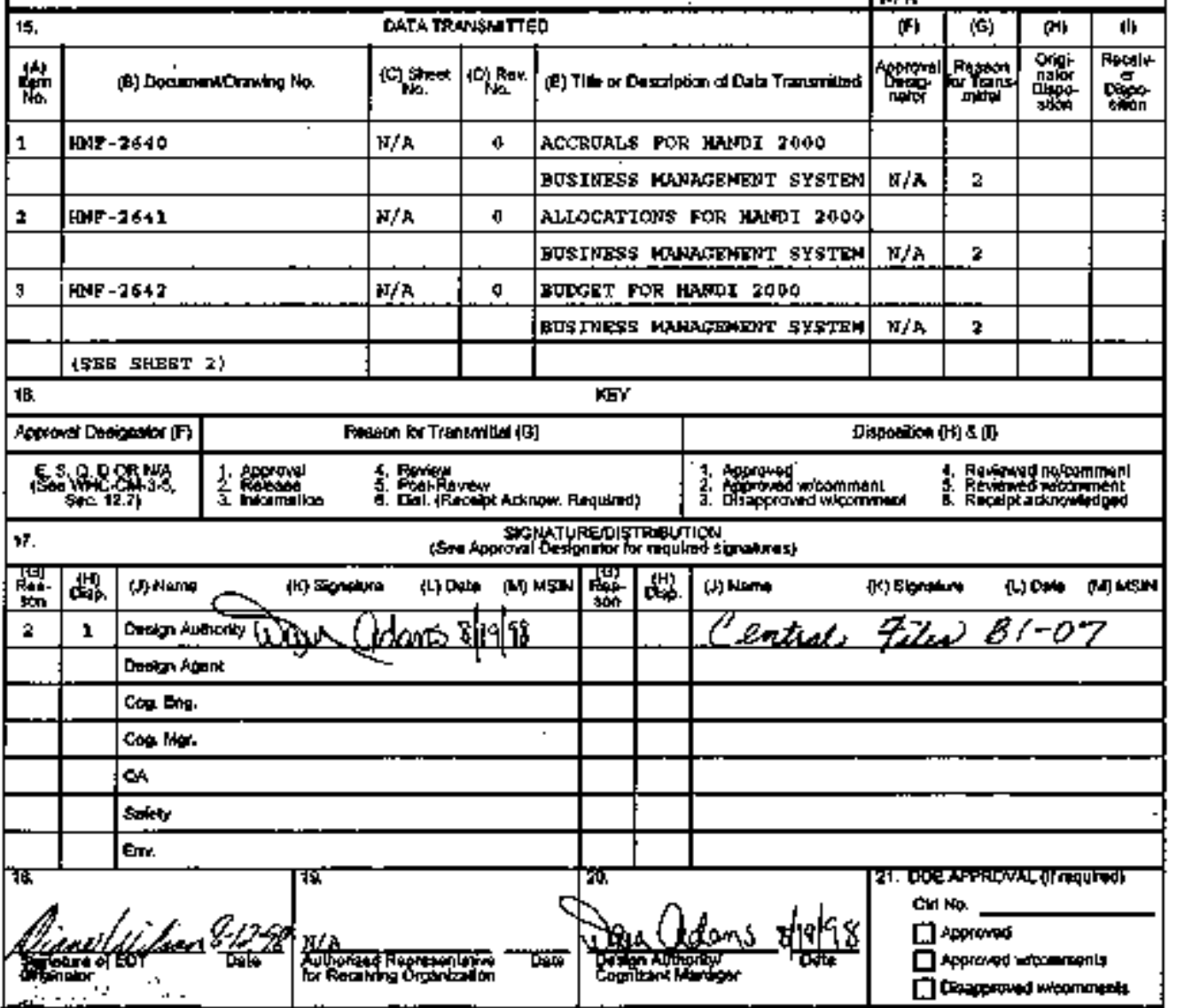




\begin{tabular}{|c|c|c|c|c|c|c|c|c|}
\hline \multirow{2}{*}{\multicolumn{2}{|c|}{ 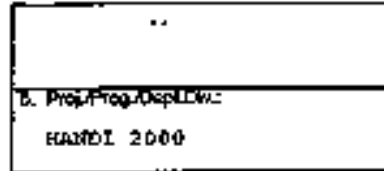 }} & \multicolumn{7}{|c|}{$\begin{array}{l}\text { ENGINEERING DATA TRANSHITTAL } \\
\text { WCONTIMHAWN PA(E) }\end{array}$} \\
\hline & & \multicolumn{3}{|c|}{ 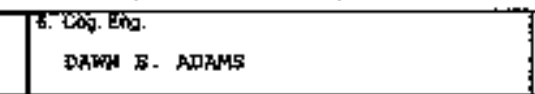 } & \multicolumn{2}{|c|}{ 1. E10 62336} & \multicolumn{2}{|c|}{ Poge 2 of 4} \\
\hline \multicolumn{2}{|l|}{15.} & \multicolumn{3}{|c|}{ DAY A TRADLSLTTTED } & IF & 13) & (thin & in \\
\hline $\lim _{\text {Na }}$ & 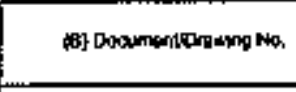 & $\sin _{n+a}$ & 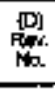 & 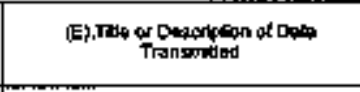 & 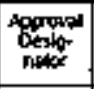 & 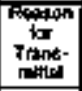 & 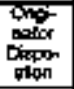 & 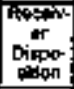 \\
\hline \multirow[t]{3}{*}{4} & ENF:2746 & $x / 2$ & D & PIT ARP AMSLYSIG PGA & $\omega / \lambda$ & z & & \\
\hline & & & & HARDI 2000 踷YNEea & & & & \\
\hline & & & & MAYTAGENERT \$YETEM & & & & \\
\hline \multirow[t]{3}{*}{$s$} & HerF-2643 & $\mathrm{n} / \mathrm{a}$ & t & CLOSIMG PROCEMURT FOR & $\boldsymbol{m} / \mathbf{R}$ & 2 & & \\
\hline & & & & ELARDI 2000 DUSINRSS & & & & \\
\hline & & & & Mustagentevt aYeTEA & & & & \\
\hline \multirow[t]{3}{*}{6} & Fog-2644 & $\mathrm{A} / \mathrm{A}$ & 0 & PIXEO AGEETA ACOONMTING & $w / \mathbf{x}$ & 2 & & \\
\hline & . & & & POR HANDI JOAO EUALNBAG & & & & \\
\hline & & & & MANAGBAEST SYSTEA & & & & \\
\hline \multirow[t]{3}{*}{7} & HAF-2645 & $\mathrm{D} / \mathrm{A}$ & 0 & FUNBG COMTAOL FOR HAMET & $\mathrm{n} / \mathrm{k}$ & $\mathbf{2}$ & & \\
\hline & & & & 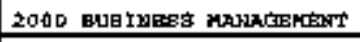 & & & & \\
\hline & & & & EYrgTEN & & & & \\
\hline \multirow[t]{4}{*}{$\boldsymbol{k}$} & 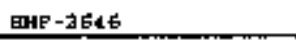 & $\mathrm{H} / \mathrm{A}$ & 0 & 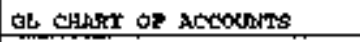 & $N / \lambda$ & s & & \\
\hline & & & & 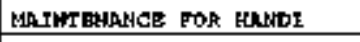 & & & & \\
\hline & & & & 2000 GUEINES9 MRAMGEHEST & & & & \\
\hline & & & & SYSTEK & & & & \\
\hline \multirow[t]{3}{*}{2} & EसHF -2647 & $w / A$ & 0 & 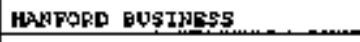 & $\mathbf{N} / \mathbf{A}$ & 2 & & \\
\hline & & & & STRUCTURE POR BUGLMES & & & & \\
\hline & & & & MANAMEMENT SYGTEM & & & & \\
\hline \multirow[t]{3}{*}{10} & Letp - 264 & $\mathrm{N} / \mathrm{A}$ & 0 & INNENTORY PRDCRASBS & $\mathrm{N} / \mathrm{h}$ & 2 & & \\
\hline & & & & POR HANDI 2000 gUSTATSS & & & & \\
\hline & & & & MHANGENEST EYRETEN & & & & \\
\hline \multirow[t]{3}{*}{11} & HAFF, 2649 & $\pi / \pi$ & D & INVOICE/CISCAE FOR HALEI & $n, / a$ & $z$ & & \\
\hline & & & & 2000 日UEIMESA WBUAGEAENT & & & & \\
\hline & & & & SHGTEM & & & & \\
\hline \multirow[t]{3}{*}{17} & Lnp-asso & $\boldsymbol{N} / \boldsymbol{\lambda}$ & $\Delta$ & IRBOR COSTING FOA KRMTI & $\mathrm{A} / \mathrm{A}$ & 2 & & \\
\hline & & & & 2000 DUSINESS MAMGENEST & & & & \\
\hline & & & & SYSTEN & & & & \\
\hline \multirow[t]{5}{*}{13.} & HRP -2651 & $\underline{n} / \mathrm{\lambda}$ & 草. & PASSPOFT-PEOPLESOFT & $\mathbf{w} / \mathrm{A}$ & 2 & & \\
\hline & & & & IUTESERATION FOR HNYRI & & & & \\
\hline & & & & 2000 BULINESB MARAGEHENT & & & & \\
\hline & & & & SYGTEM & & & & \\
\hline & SCOMrivere on As 31 & & & & & & & \\
\hline
\end{tabular}


ENOINEERINO DATA TRANSMITTAL

tCCNTHWATLON PMOE)

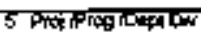

EHWDT 2000

\section{T. $\cos$ End \\ DAWM E ADAMS}

75

息 Nov

$14 \quad \mathrm{HTF}-2657$

\begin{tabular}{|l|l|}
\hline & $\ldots$ \\
\hline &
\end{tabular}

15 AMP-2659

\begin{tabular}{r|l|l}
\hline & \\
\hline & \\
\hline 10 & & \\
\hline
\end{tabular}

15 HNAP-2594

17 HNF - 2655

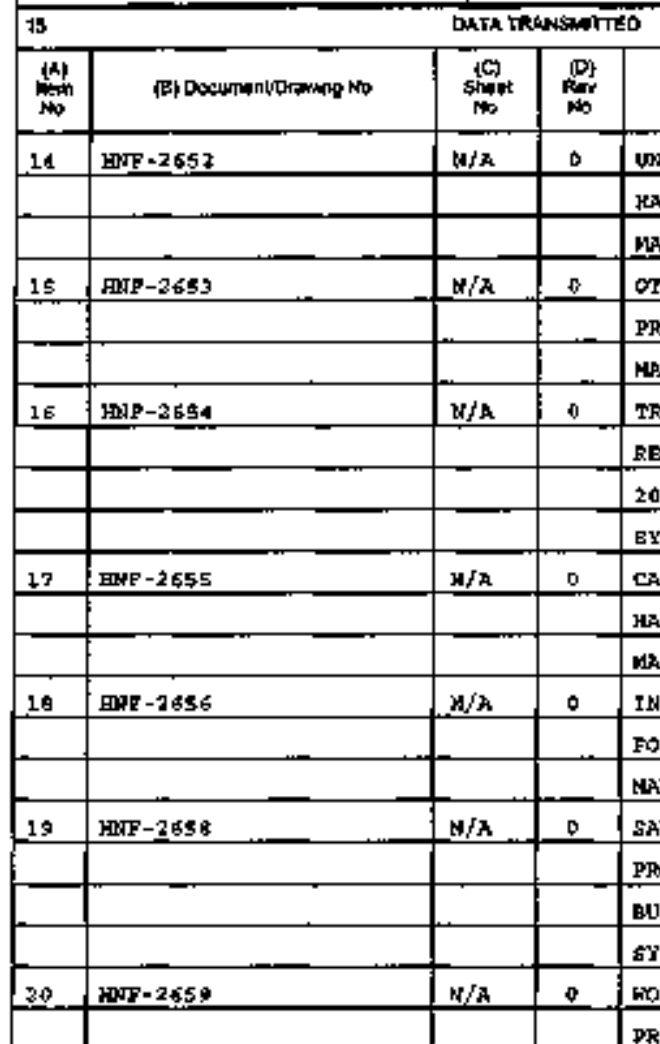

10 MaF - 2656

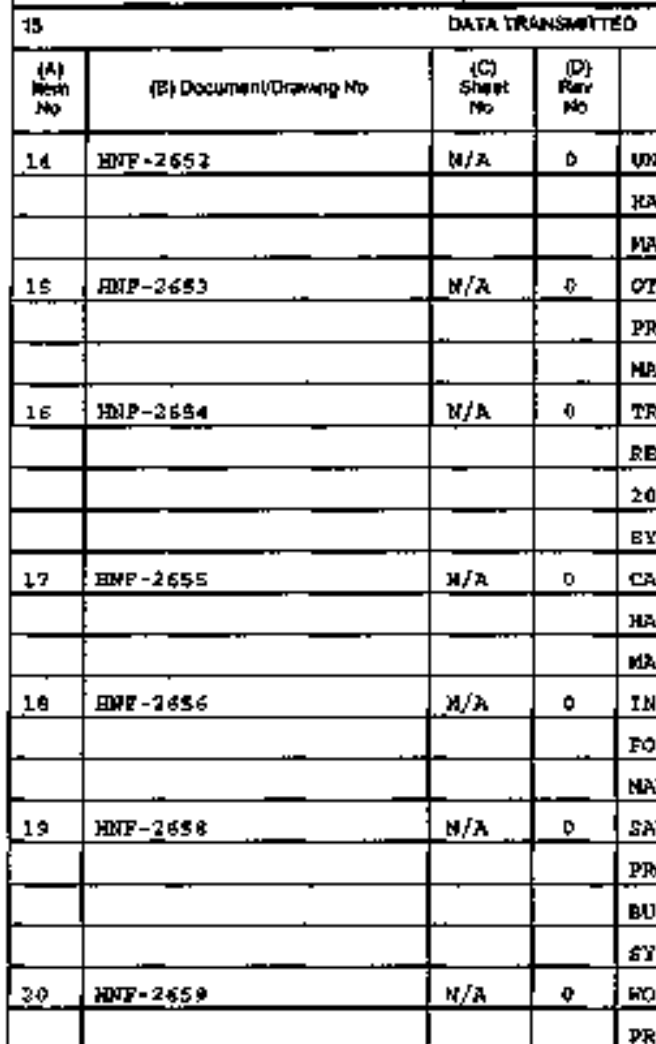

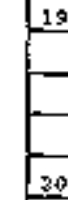

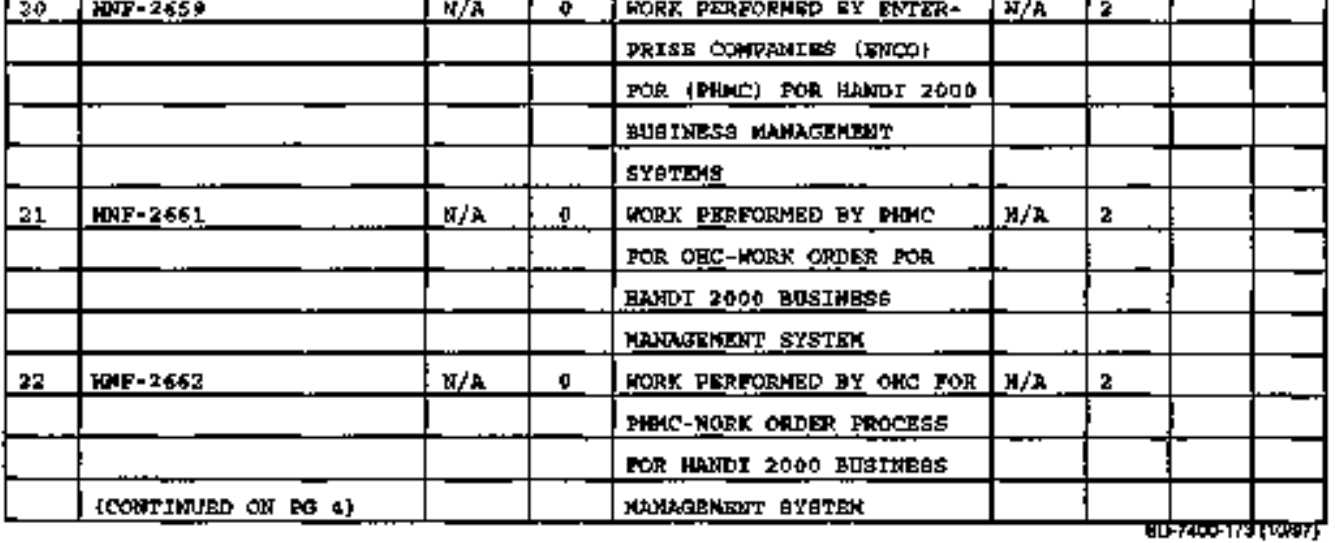




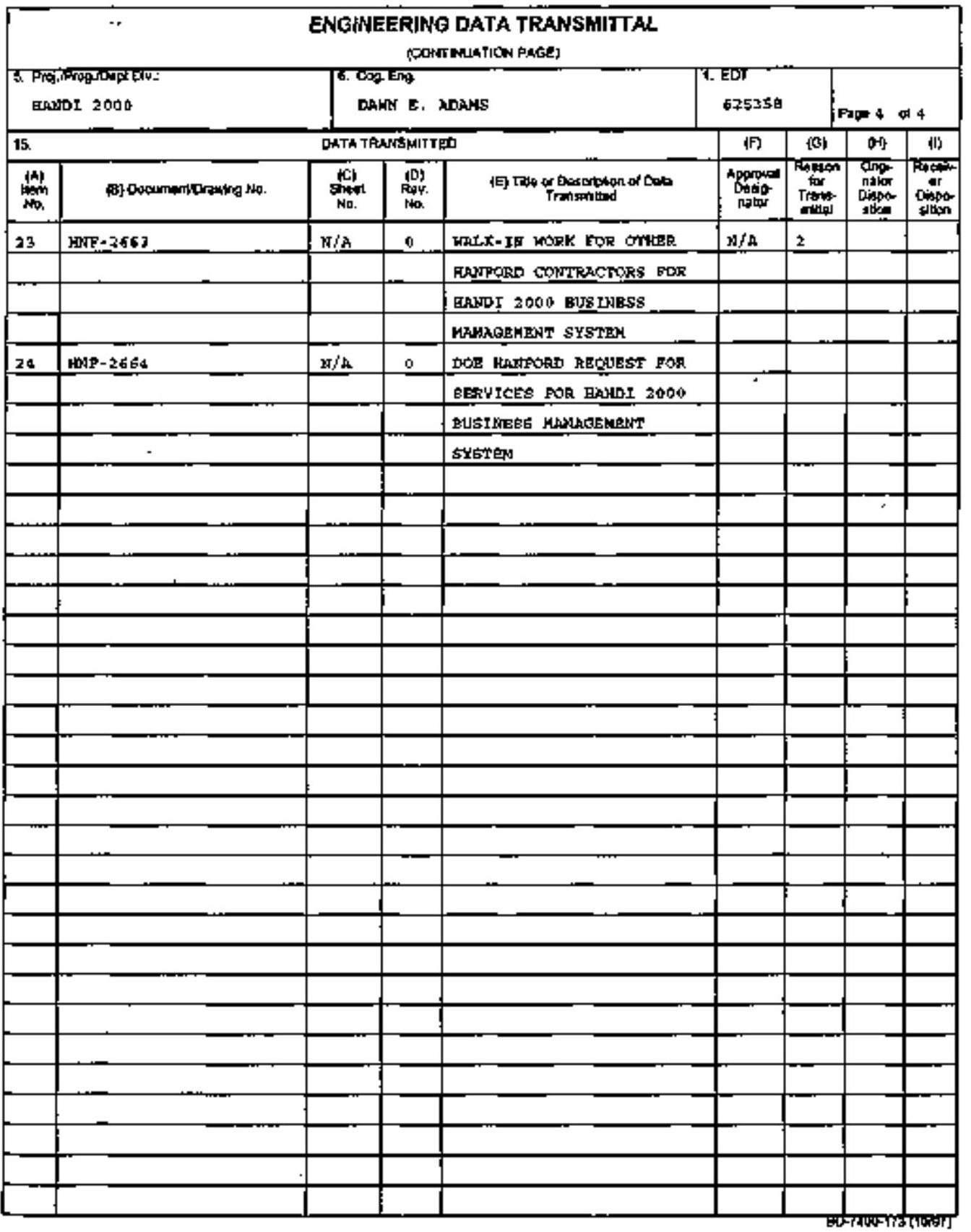




\title{
PASSPORT-PEOPLESOFT INTEGRATION FOR HANDI 2000 BUSINESS MANAGENENT SYSTEM
}

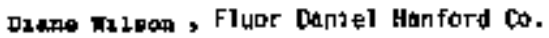 \\ HSN $61-22$ \\ Richland, WA 99362 \\ US Depertrient of Energy Contract DE ACO6-96RL13200

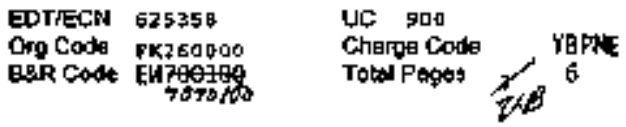

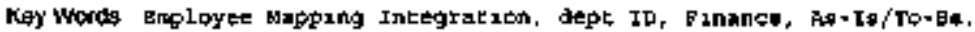
AD, Contract Mnagewant, Invantary, Purahasing, Gonoral Ladgax, Project cotering

Absiract The integracion between the Pecplesteft applicatiane and panspart modules are sectiplithed wibh an of the ahell pockage developed by

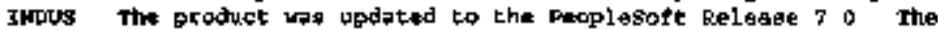
integration praduct intersoto vith Aata from miltiple productu wathrn Pasaport and Peoplasort

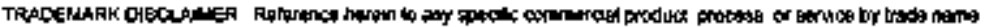

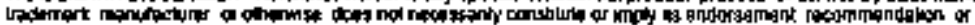

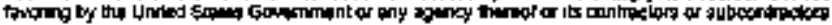

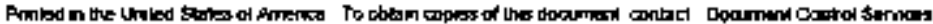

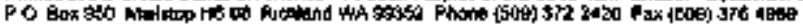

Passport is a tradeark of Indus corp. Peaplesaft 15 a trademark af Indus corp.
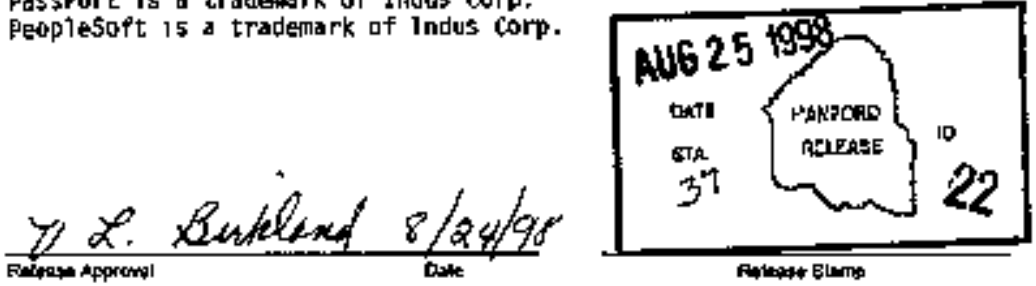

Approved For Public Release 
HNF-2651, Rê4 + O

\section{Memorandum}

To:
D.E. Admons 01-2I
M. Byrd
H2- 08 ,
A.A. Certer
H2-19,
C.R. Hopkins GI-57,

K. B. Adamsons H2-19

R.C.Cortess H2-19.

J.A. Caldpell G1-22,

R.J. McFadzean H2-19

Fron: P. C. Felts

Date: April 17, 1998

Ret Peoplesoft General Ledget / Projet Costing - Business System Inplementalion Strsions Final Documentation

\section{HANDI 2000 - Floance}

Atleched for your informotion is the complate set of documentation of the work flow analy gis from the Business System Implementation (BSI) Sessions.

One of the goals of findiving documemation from the BsJ Sessions is to use the documients as a communtication tooul.

Other goals of the BSI sessiong were to validate the As-Is frocess, and describe the viston of the To-Be process that fit the baseline soffwane procesoes. In the futhure, this docomentation will be accessitte ejectronically via a read-only shared area.

I thank you and your staff for your support during this information gatherting and etvisioning slage of the thew system inplementation project

If you have any questipnt, I can be reached on 376-0367 or via email

Allachinert 
Date:

$4 / 1798$

Documentation: Finance Business System Implementat|on (BS) Sestione

Processes Included:

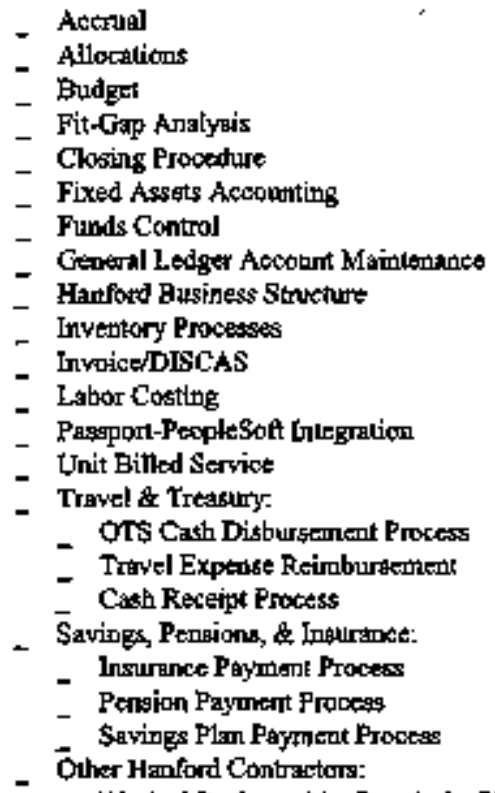

- Warked Pafumed by Enco's for PHMC

- Warked Pafiomed by Enos's for OHC

- Worked Performed by PHMC for OHC - Wark Osder

- Worked Performed by OHC for PHMC - Work Ordor Process

- worked Performed by PHMC for OHC - Wall Ir

- Worked Performed by PHMC for DOE-Richland using the Request for Service Process

FOH Projact Laad: Name

Signetuire

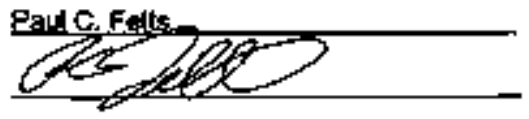




\section{Passport-PeopleSoft Integration}

\section{Overnan}

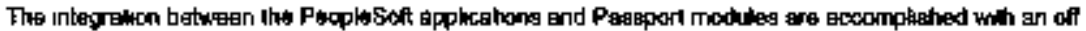

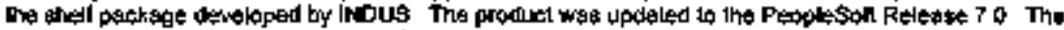

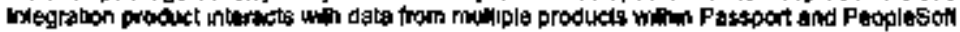

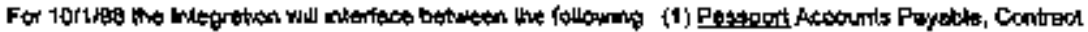

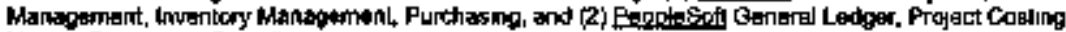
Hemen Regources, Prytoll

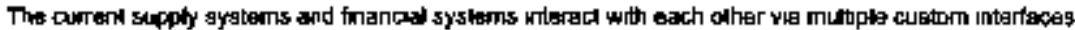

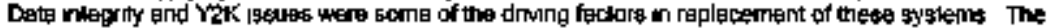

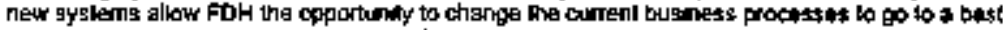

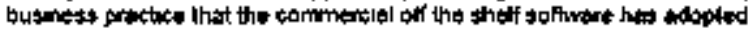

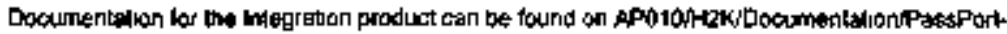
Pocpisstefted at mis doc

\section{Acsimplons}

口 The cormercal of the thalf Irtegrabon peckage deweloped by INDUS between the Patsoort

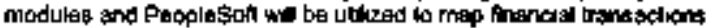

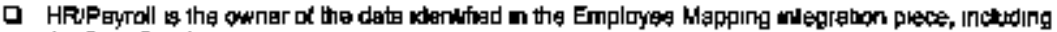
the Deptid walue

口 Finences Project Identific:lin Coet Elemends, end Code of Auccounts

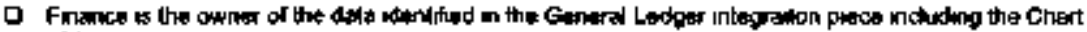
of Accounts

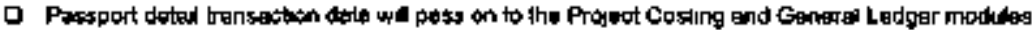

\section{Asts Procoduras}

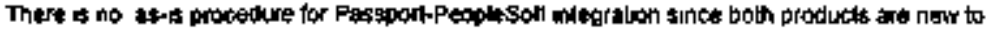
Prapict Hinlond

\section{To. Bo Procedurt}

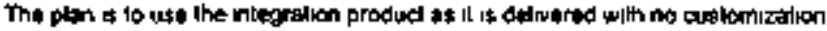




\section{mants}

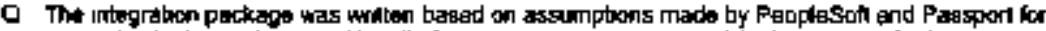

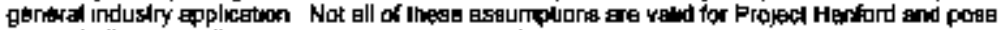

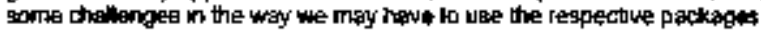

\section{Hsuta \& Acbon Rems}

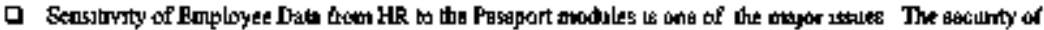

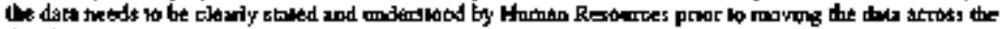
Employed Data mapping

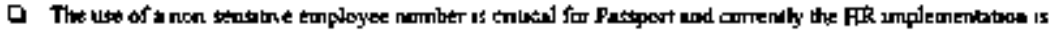

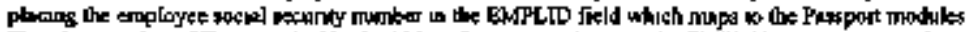

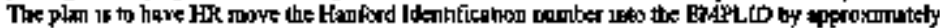

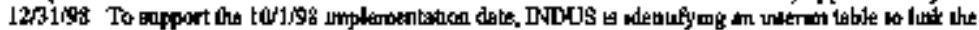

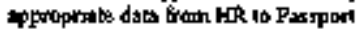

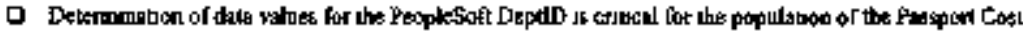

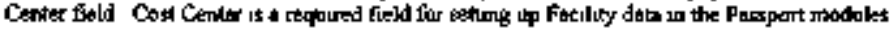

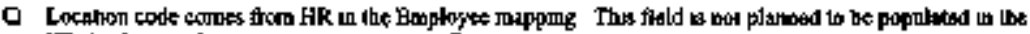
HR databese and muy custe sothe ditots to Paspon

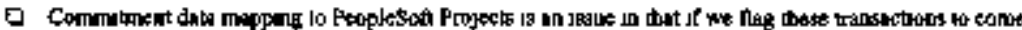

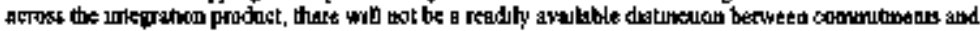
Petents coste

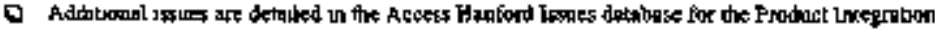


HANDI 2004 Fluer Dantal Funford - PeopleSon Finanelats PASSPORT-PEOPLESOFT INTEGRATION 